\title{
A MODIFIED METHOD FOR FABRICATION POROUS SILICON NITRIDE/SILICON CARBIDE NANOCOMPOSITES
}

\author{
M. K. Hassan, \\ Department of Mechanical Design and Materials, High Institute of Energy, \\ South Valley University, Aswan, Egypt. mkorrany@msn.com
}

\section{M. Dewidar, and}

Material \& Fracture Lab., Department of Mechanical Design, Chonbuk

National University, Duckjin 1-664-14, Jeonju, JB561-756, South Korea.

dewidar5@hotmail.com

\section{S. Z. El-Abeden}

Department of Production Engineering and Design, Faculty of Engineering Minia University, 61111, Minia, Egypt.

(Received December 2, 2006 Accepted February 12, 2007)

\begin{abstract}
The synthesis and characterization of porous silicon nitridel silicon carbide nanocomposites have been studied. Porous $\mathrm{Si}_{3} \mathrm{~N}_{4} / \mathrm{SiC}$ nanocomposites with 30 and 60 vol.\% SiC were fabricated by two sintering steps of the mixture powder of $\mathrm{Si}_{3} \mathrm{~N}_{4}$, carbon, and yttria $\mathrm{Y}_{2} \mathrm{O}_{3}$. The powder mixtures were uniaxially pressed using $25 \mathrm{MPa}$ and sintered in nitrogen gas at 1650, 1750, and $1850^{\circ} \mathrm{C}$ for 1,2 , and 3 h respectively. The characteristics of porous $\mathrm{Si}_{3} \mathrm{~N}_{4} / \mathrm{SiC}$ nanocomposites were investigated by using $X$-ray diffraction and SEM. Also the compressive strength and microstructure of the $\mathrm{Si}_{3} \mathrm{~N}_{4} / \mathrm{SiC}$ nanocomposites were investigated. The strength of $\mathrm{Si}_{3} \mathrm{~N}_{4} / \mathrm{SiC}$ nanocomposites depends mainly on the sintering temperature, and the holding time of the sintering. The best holding time for sintering at $1650^{\circ} \mathrm{C}, 1750^{\circ} \mathrm{C}$, and $1850^{\circ} \mathrm{C}$ are 1,2 , and $3 \mathrm{~h}$ respectively.
\end{abstract}

KEYWORDS: Silicon nitridel silicon carbide; Nanocomposites; Porous; Sintering; Chemical reaction

\section{INTRODUCTION}

There has been interest in the creation of porous materials for many applications such as molten metal filters, lightweight cores for sandwich panels, sensors, heat exchanger, and dust or soot collectors $[1,2]$. The advantages of pores are the reducing the weight of structures and Young's modulus and increasing the surface area. Control the porosity and pore geometry and enhancement of the mechanical properties of the porous structure are critically important to improve the performance and the reliability of these structures [3, 4]. 
Silicon nitride $\left(\mathrm{Si}_{3} \mathrm{~N}_{4}\right)$ ceramics and its composite, dense or porous are important structural materials for high temperature applications, due to excellent thermal and mechanical properties [5-7]. The second phase addition, such as whiskers, platelets or fibers, to the silicon nitride matrix aim to improve some specific mechanical properties [8]. Silicon carbide ( $\mathrm{SiC}$ ) whiskers has been widely used as reinforcing agent for covalent [9] or oxides ceramics due to its high strength, elastic modulus and chemical inertness at elevated temperature, causing substantial improvements in fracture toughness and slowcrack-growth resistance [10]

Many processing techniques have been developed to manufacture porous $\mathrm{Si}_{3} \mathrm{~N}_{4}$ ceramics and its composite materials for functional or structural applications [11-13]. Porous $\mathrm{Si}_{3} \mathrm{~N}_{4}$ ceramics can be fabricated by either using the fugitive substance [14], or by controlled sintering of $\mathrm{Si}_{3} \mathrm{~N}_{4}$ powder with low content of sintering aid [15], or partial hot-pressing [16]. $\mathrm{Si}_{3} \mathrm{~N}_{4}$ possesses two crystalline phases, $\alpha-\mathrm{Si}_{3} \mathrm{~N}_{4}$ (stable at room temperature) and $\beta-\mathrm{Si}_{3} \mathrm{~N}_{4}$ (stable at high temperature), both of which are hexagonal, differing only in the lattice parameter "c"'. Porous $\mathrm{Si}_{3} \mathrm{~N}_{4}$ ceramics with a microstructure of $\beta-\mathrm{Si}_{3} \mathrm{~N}_{4}$ grains shows superior mechanical properties, such as high strength, good thermal shock resistance, and high strain and damage tolerance $[17,18]$.

By using the fugitive substance, such as starch, it is possible to adjust the porosity by changing the starch content. However, the large sized fugitive substance degrades the shaping property of the powder mixture. Alternatively, it is difficult to produce porous $\mathrm{Si}_{3} \mathrm{~N}_{4}$ ceramics with fine pores [19], due to the restriction of the particle size of fugitive substance. Increasing the porosity with keeping the fine pore size as well as good shaping behavior and sinterability is still a unresolved problem in the fabrication of porous ceramics.

The work of J-F Yang et al. [12, 15] have demonstrated a successful means to fabricate porous $\mathrm{Si}_{3} \mathrm{~N}_{4}$ ceramics with high porosity through sintering powder mixture of $\mathrm{Si}_{3} \mathrm{~N}_{4}, 0.7-3.4 \mathrm{wt} \%$ carbon and some sintering aid. Reactions between $\mathrm{SiO}_{2}$ or $\mathrm{Si}_{3} \mathrm{~N}_{4}$ and the added carbon powder occur in the ceramic green body [20]:

$$
\begin{aligned}
& 2 \mathrm{C}+\mathrm{SiO}_{2} \rightarrow \mathrm{SiC}+2 \mathrm{CO} \\
& 3 \mathrm{C}+\mathrm{Si}_{3} \mathrm{~N}_{4} \rightarrow 3 \mathrm{SiC}+2 \mathrm{~N}_{2}
\end{aligned}
$$

The boundary temperature for the conversion from $\mathrm{Si}_{3} \mathrm{~N}_{4}$ to $\mathrm{SiC}$ has been estimated as approximately $1435^{\circ} \mathrm{C}$, and the formation of $\mathrm{SiC}$ starts between 1400 and $1450^{\circ} \mathrm{C}$ [21]. Reaction (1) occurs more easily than does reaction (2) in the $\mathrm{Si}_{3} \mathrm{~N}_{4}-\mathrm{SiO}_{2}-\mathrm{C}$ system [22]. After $\mathrm{SiO}_{2}$ on the $\mathrm{Si}_{3} \mathrm{~N}_{4}$ surface is consumed, the remained carbon reacts with $\mathrm{Si}_{3} \mathrm{~N}_{4}$, according to reaction (2). The $\mathrm{Si}_{3} \mathrm{~N}_{4}$ grains would be bonded together by the reaction-formed $\mathrm{SiC}$ particles located at the grain boundaries, and the shrinkage of $\mathrm{Si}_{3} \mathrm{~N}_{4}$ ceramics was decreased. 
The aim of this work is to study the fabrication process of synthesis of porous $\mathrm{Si}_{3} \mathrm{~N}_{4} / \mathrm{SiC}$ nanocomposites based on the reaction between $\mathrm{Si}_{3} \mathrm{~N}_{4}$ and carbon. Also the formation of $\mathrm{SiC}$ nanoparticles, density, mechanical properties and microstructure of porous $\mathrm{Si}_{3} \mathrm{~N}_{4} / \mathrm{SiC}$ are investigated.

\section{EXPERIMENTAL PROCEDURE}

Silicon nitride powder $\left(\mathrm{Si}_{3} \mathrm{~N}_{4}\right)$ with high purity $(\mathrm{SN}-\mathrm{E} 10, \alpha$ ratio: $>95 \%$, mean particle size: $500 \mathrm{~nm}$, main impurities by weight: $\mathrm{O}=1.6 \% \mathrm{C}<0.2 \%, \mathrm{Cl}, \mathrm{Fe}, \mathrm{Ca}$, and $\mathrm{Al}_{2} \mathrm{O}_{3}<50 \mathrm{ppm}$ ) was supplied by UBE Industrial Ltd, Tokyo, Japan. Carbon powder with mean particles size is $13 \mathrm{~nm}$ was supplied by Mitsubishi Chemical Corp., Tokyo, Japan. Yttrium oxide $\left(\mathrm{Y}_{2} \mathrm{O}_{3}\right)$ with mean particles size is $15 \mathrm{~nm}$, which used as sintering additive was supplied by Shin-etsu Chemical Co, Ltd, Tokyo, Japan. To fabricate the porous $\mathrm{Si}_{3} \mathrm{~N}_{4} / \mathrm{SiC}$ nanocomposites with $30 \%$ and $60 \mathrm{vol} \% \mathrm{SiC}$ which are volume fractions of solid parts of $\mathrm{Si}_{3} \mathrm{~N}_{4}$ and $\mathrm{SiC}$ in the composites, the following compositions of the powder mixture were used: 87.13 and $81.30 \mathrm{wt} \% \mathrm{Si}_{3} \mathrm{~N}_{4}, 7.87$, and $13.7 \mathrm{wt} \%$ carbon, respectively. 5 $\mathrm{wt} \% \mathrm{Y}_{2} \mathrm{O}_{3}$ as the sintering additive was added in. The values of each powder weight were calculated according to the reactions 1 , and 2 [20]. The mixtures were firstly wet milled in ethanol for $24 \mathrm{hr}$. using alumina balls in nylon jars. After milling, the slurry was dried at temperature $80^{\circ} \mathrm{C}$ under vacuum for $24 \mathrm{hr}$. Then, the mixtures were sieved. The powder mixtures were uniaxially pressed using press machine (Hydraulic unit Model 3912, Carver, INC USA). The compaction pressure was constant at $25 \mathrm{MPa}$. Two molds were used to fabricate the samples with diameter $12 \mathrm{~mm}$ and height $6 \mathrm{~mm}$.

The green samples were put on graphite crucible coated by a layer of boron nitride and placed in the furnace to be sintered. The temperature of presintering was $1600^{\circ} \mathrm{C}$ with heating rate $20^{\circ} \mathrm{C} / \mathrm{min}$ for one hour to obtain $\mathrm{SiC}$ particles through the reaction. The temperatures of sintering include three levels which carried out under nitrogen atmosphere were $1650^{\circ} \mathrm{C}, 1750^{\circ} \mathrm{C}$, and $1850^{\circ} \mathrm{C}$ with heating rate $10^{\circ} \mathrm{C} / \mathrm{min}$. The holding times for each sintering temperature were $1 \mathrm{hr}, 2 \mathrm{hr}$, and $3 \mathrm{hr}$. The density and porosity of the sintered parts were measured by Archimedes displacement method. Figure 1 shows the schematic of sintering process. The porosity was calculated from the relative density and theoretical density, which was calculated by the rule of the mixtures. Crystalline phases of sintered samples were identified by X-ray diffraction (XRD, Model D/MAX 2500, Rigaku Co. Ltd, Tokyo, Japan). The analysis was achieved at 40 $\mathrm{kV}$ and $100 \mathrm{~mA}$ sing $\mathrm{CuK}_{\alpha}$ radiation, a step width of $0.02^{\circ}$, and counting time of $0.4 \mathrm{~s}$. Compressive tests were carried out using specimens subjected to uniaxial compressive loading at a cross head speed of $0.5 \mathrm{~mm} / \mathrm{min}$ using universal test machine (Instron 4206, USA). The microstructures were examined using 
scanning electronic microscopy (SEM, Model JSM-640, Jeol Co. Ltd, Tokyo, Japan).

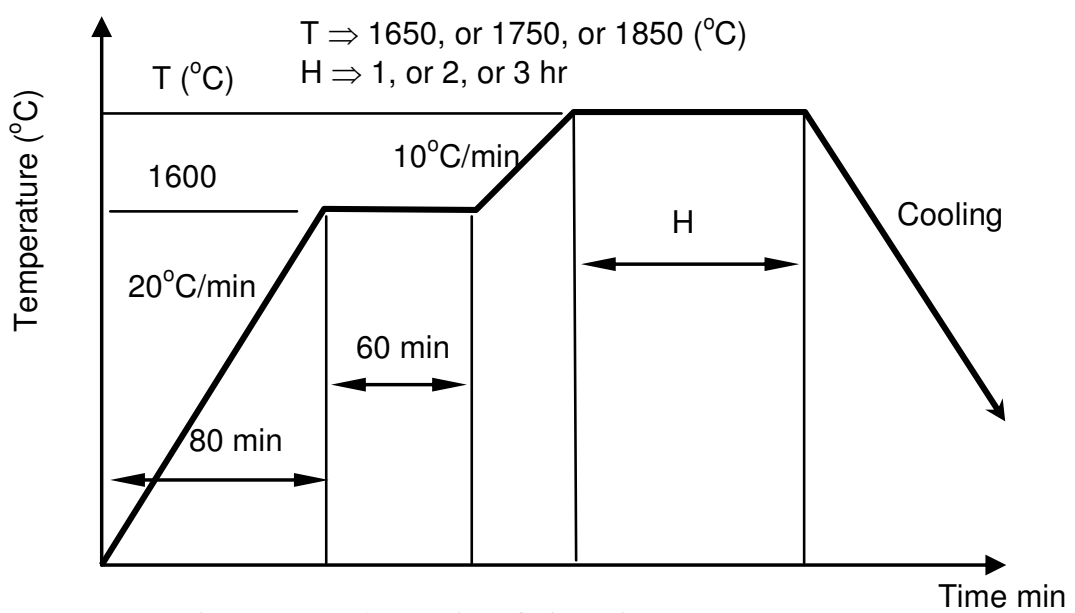

Figure 1. Schematic of sintering process

\section{RESULTS AND DISCUSSIONS}

\subsection{Weight Loss and Porosity}

The measured weight loss was shown in Figure 2. In general, the weight loss of the samples increased with increasing sintering temperature and sintering time. The weight loss was due to the release of nitrogen and carbon monoxide from the samples during the sintering according to the equations 1 and 2. According to reaction 1 and 2, weight loss after sintering are 12.28 and $21.12 \%$ theoretically for the composites with 30 and $60 \mathrm{vol} \% \mathrm{SiC}$, respectively [12]. Weight loss of samples sintered at $1650^{\circ} \mathrm{C}$ for 1.0 and $2.0 \mathrm{hr}$ was lower than the theoretical value, while that of samples sintered at 1750 and $1850^{\circ} \mathrm{C}$ were almost higher. The low weight loss at low sintering temperature was come from a fact that the reaction was not completed indicating that it needs a high temperature to transfer all carbon to $\mathrm{SiC}$. On the other hand, the higher loss at higher temperature, 1750 and $1850^{\circ} \mathrm{C}$ was come from a fact that a mass of carbon was depleted during the sintering and the reaction was completed, which some of $\mathrm{Si}_{3} \mathrm{~N}_{4}$ was decomposed to $\mathrm{Si}$ and $\mathrm{N}_{2}$ according the following reaction [20]:

$$
\mathrm{Si}_{3} \mathrm{~N}_{4} \leftrightarrow 3 \mathrm{Si}+2 \mathrm{~N}_{2}
$$

The densification of $\mathrm{Si}_{3} \mathrm{~N}_{4}$ ceramic using $\mathrm{Y}_{2} \mathrm{O}_{3}$ oxide as sintering additives begin at temperature above $1400^{\circ} \mathrm{C}$ [23] at which the glass-phase formed and particle arrangement was the main densification mechanism. The reaction between carbon and $\mathrm{Si}_{3} \mathrm{~N}_{4}$ also begin at this temperature, and prior to it, reaction between carbon and surface $\mathrm{SiO}_{2}$ begins according to the reaction 1 , and 2. 
The glass phase plays an important role in the $\mathrm{Si}_{3} \mathrm{~N}_{4}$ particles arrangement and the densification of $\mathrm{Si}_{3} \mathrm{~N}_{4}$ ceramics by liquid phase sintering dependent on the characteristics of glass phase such as amount of viscosity [24]. At relatively low temperature, less than $1600^{\circ} \mathrm{C}$, the viscosity of glass phase is high, so the densification is limited [24]. As the reactions begin almost simultaneously with the glass formation, the bonding of the $\mathrm{Si}_{3} \mathrm{~N}_{4}$ particles by the reaction formed $\mathrm{SiC}$ particles is very likely to obstacle the movement of $\mathrm{Si}_{3} \mathrm{~N}_{4}$ particles and restrains their arrangement. With increase the temperature of sintering, the increased viscosity of glass phase indicated the densification tendency as the bonding among $\mathrm{Si}_{3} \mathrm{~N}_{4}$ grains was strong; hardly did the grain rearrangement take place. Low sintering shrinkage (within 2\%) and high porosity after sintering were resulted in. Due to the low shrinkage and high weight loss during the reactions the relative densities after sintering were lower than the relative densities of the green parts as can be seen from Figure 3. In addition, the higher content of the $\mathrm{SiC}$ reaction formed, the lower the relative density and the higher the porosity. The relative densities were found to be ranged from 35 to $50 \%$, i.e., the porosity were adjustable from 50 to $65 \%$
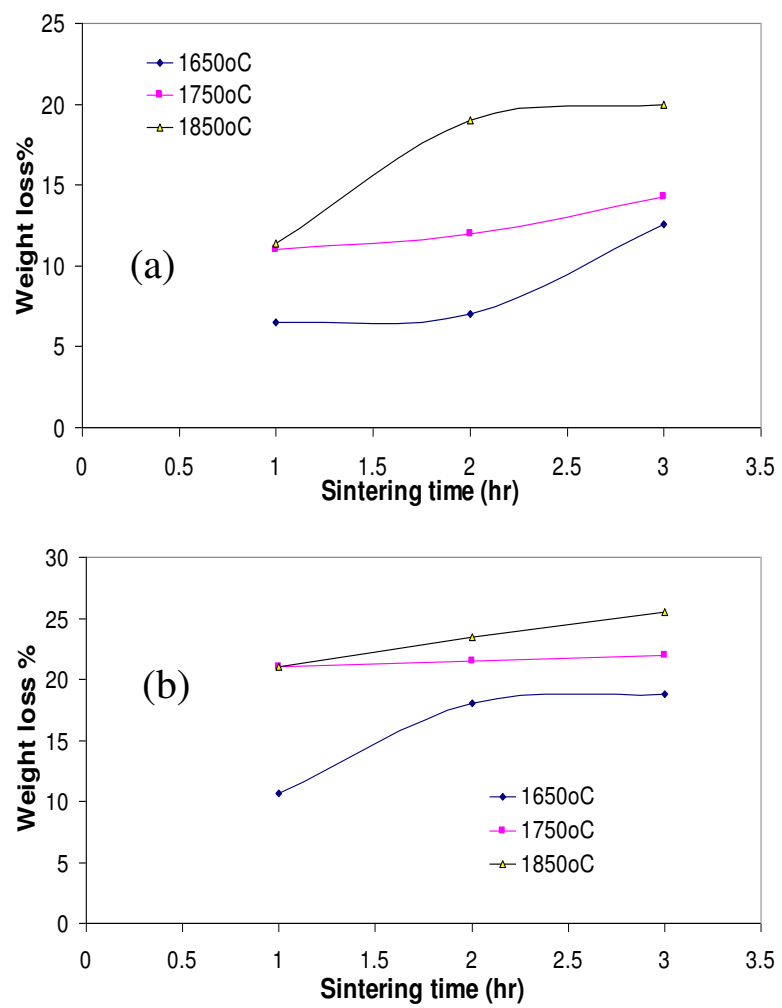

Figure 2. Weight loss as a function of sintering time of Si3N4/SiC at different sintering temperature a) $30 \mathrm{vol} \% \mathrm{SiC}$, and b) $60 \mathrm{vol} \% \mathrm{SiC}$. 

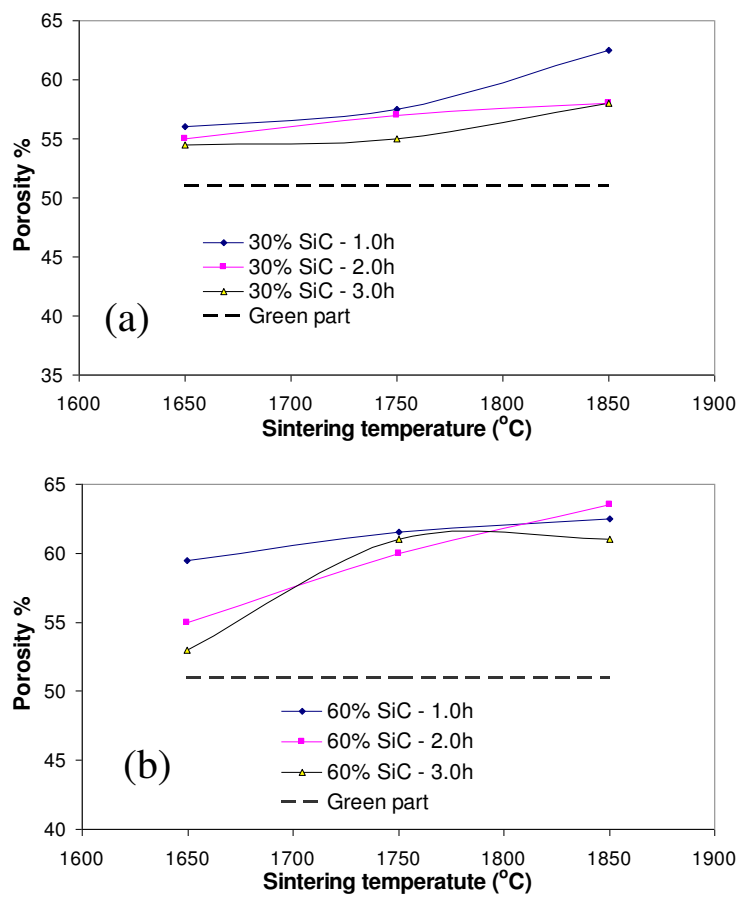

Figure 3. Porosity of $\mathrm{Si}_{3} \mathrm{~N}_{4} / \mathrm{SiC}$ as a function of different sintering temperature a) 30 vol\% $\mathrm{SiC}$, and b) $60 \mathrm{vol} \% \mathrm{SiC}$

\subsection{XRD}

The XRD patterns for samples sintered at 1650,1750 , and $1850^{\circ} \mathrm{C}$ are shown from Figure 4. For the samples which sintered at $1650^{\circ} \mathrm{C}$, the formation of $\mathrm{SiC}$ could be detected. However, the peaks of $\mathrm{SiC}$ are not so much, it can be seen that the reaction between $\alpha-\mathrm{Si}_{3} \mathrm{~N}_{4}$ and carbon took place when sintered at $1650^{\circ} \mathrm{C}$. The graphs of XRD patterns for samples sintered for 1.0, 2.0, and $3.0 \mathrm{~h}$ are almost have the same peaks, and it is only different in intensity. This means that the sintering temperature play more important role in the transformation of phases than the sintering time. At the temperature of $1750^{\circ} \mathrm{C}$, the reaction took place more much than that of at $1650^{\circ} \mathrm{C}$. In addition, at the temperature of $1750^{\circ} \mathrm{C}$ the $\beta \mathrm{Si}_{3} \mathrm{~N}_{4}$ was detected. At sintering temperature $1850^{\circ} \mathrm{C}$, the reaction took place completely, so the $\beta \mathrm{Si}_{3} \mathrm{~N}_{4}$ and $\mathrm{SiC}$ were detected. In addition, some other traces phases such as $\mathrm{Y}_{2} \mathrm{Si}_{3} \mathrm{O}_{3} \mathrm{~N}_{4}$ and $\mathrm{YNSiO}_{2}$ formed from the sintering additive $\mathrm{Y}_{2} \mathrm{O}_{3}$ were also detected. The resultant liquid phase solidify, during cooling, forming a partially crystalline intergranular phase. Baldacim et. al [25] reported that, for the $2.5 \mathrm{wt} . \% \mathrm{Y} 2 \mathrm{O} 3$ compositions, crystalline intergranular phases related to sintering aids were not detected by XRD, due to its small amount, the additive probably remained in amorphous conditions as grainboundary phase. 


\subsection{Compressive Strength}

Figure 5 shows the compressive strength of the samples with 30 and $60 \mathrm{vol} \%$ $\mathrm{SiC}$ as a function of sintering temperature. As can be seen, the compressive strength of the samples with $30 \mathrm{vol} \%$ is higher than that of the samples with 60 vol\% $\mathrm{SiC}$. It means that the more distribution of $\mathrm{SiC}$ formed due to the reaction between $\mathrm{Si}_{3} \mathrm{~N}_{4}$ and $\mathrm{C}$ in the porous nanocomposites leads to decrease the compressive strength. The maximum compressive strength is reached to 87 $\mathrm{MPa}$ at sintering temperature of $1750^{\circ} \mathrm{C}$ and holding time $2 \mathrm{~h}$ for $30 \mathrm{vol} \% \mathrm{SiC}$ samples. Comparing with sintering temperature to obtain the high strength of porous nanocomposites, the best temperature is $1750^{\circ} \mathrm{C}$.

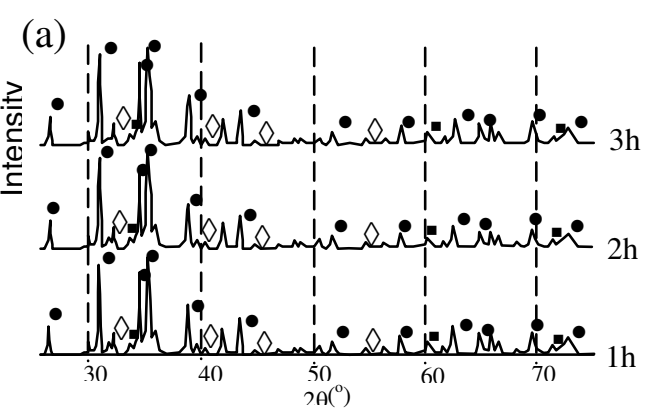

(b)
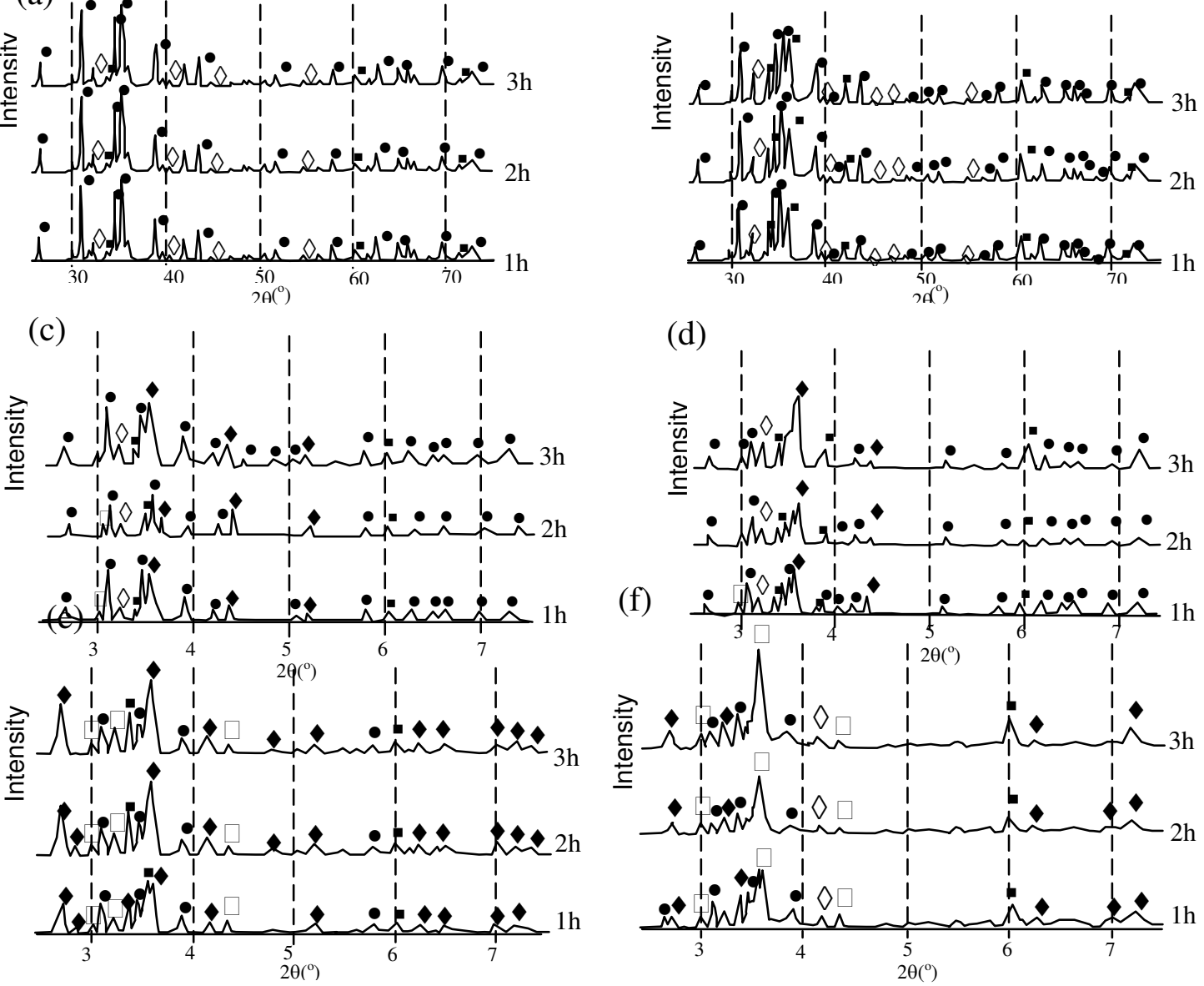

(d)

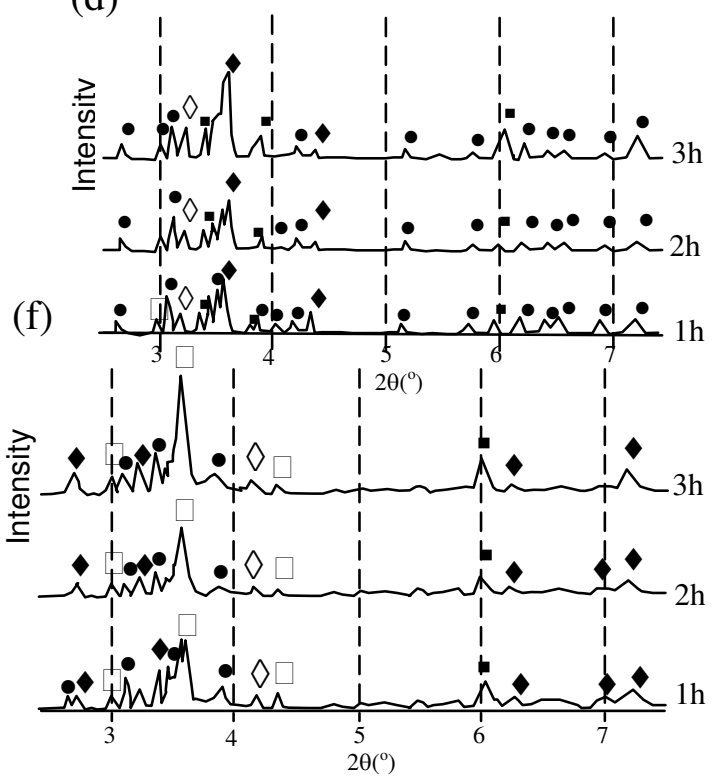

Figure 4 XRD pattern a) sintering temperature $1650^{\circ} \mathrm{C} 30 \%$, b) sintering temperature $1650^{\circ} \mathrm{C} 60 \%$, c) sintering temperature $1750^{\circ} \mathrm{C} 30 \%$, d) sintering temperature $1750^{\circ} \mathrm{C} 60 \%$, e) sintering temperature $1850^{\circ} \mathrm{C} 30 \%$, and f) sintering temperature $1850^{\circ} \mathrm{C} 60 \%$, $\left(\bullet \alpha-\mathrm{Si}_{3} \mathrm{~N}_{4}, \bullet \beta-\mathrm{Si}_{3} \mathrm{~N}_{4}, \cdot \mathrm{SiC}, \mathrm{OSi}, \diamond \mathrm{YNSiO}_{2}\right.$, and $\left.\square \mathrm{Y}_{2} \mathrm{Si}_{3} \mathrm{O}_{3} \mathrm{~N}_{4}\right)$ 


\subsection{Microstructure}

Figure 6, and 7 shows the microstructure of green and sintered parts at $1650^{\circ} \mathrm{C}$ for 1,2 , and $3 \mathrm{~h}$ with 30 , and $60 \mathrm{vol} \% \mathrm{SiC}$ respectively. The micrograph of green part exhibited very fine particles composed of fine $\alpha-\mathrm{Si}_{3} \mathrm{~N}_{4}$ particles and ultra-fine carbon particles. The $\mathrm{SiC}$ particles which were taken formed through the reaction should be very fine due to the use of carbon particle with the size $13 \mathrm{~nm}$. Equiaxial $\alpha-\mathrm{Si}_{3} \mathrm{~N}_{4}$ and carbon particles still remained due to the incomplete reaction, which also was indicated by XRD pattern. With increasing the sintering time, the $\alpha-\mathrm{Si}_{3} \mathrm{~N}_{4}$ phase developed and the pores in the porous nanocomposites increase simultaneous. When the sintering temperature increased to $1750^{\circ} \mathrm{C}$, grain growth of $\beta-\mathrm{Si}_{3} \mathrm{~N}_{4}$ was shown, the $\beta-\mathrm{Si}_{3} \mathrm{~N}_{4}$ phase resulted from the transformation of $\alpha \rightarrow \beta \mathrm{Si}_{3} \mathrm{~N}_{4}$ during sintering time and no carbon particles have be seen in Figure 8, and 9. But the SiC particles still inhibited the growth of $\mathrm{Si}_{3} \mathrm{~N}_{4}$. Similar to the dense $\mathrm{Si}_{3} \mathrm{~N}_{4} / \mathrm{SiC}$ nanocompoaites, the high $\mathrm{SiC}$ content resulted in the restrained $\beta-\mathrm{Si}_{3} \mathrm{~N}_{4}$ grain growth, as can be seen in Figures 9 and 11 for $60 \mathrm{vol} \% \mathrm{SiC}$ samples. With increasing temperature to $1850^{\circ} \mathrm{C}$, grain growth of $\beta-\mathrm{Si}_{3} \mathrm{~N}_{4}$ increased and it look as larger than that with $1750^{\circ} \mathrm{C}$ (see Figure 10 and 11 ). The $\mathrm{SiC}$ particles were still so fine. It can be seen that the $\mathrm{SiC}$ particles obtained from reaction between carbon and $\mathrm{Si}_{3} \mathrm{~N}_{4}$ has a very fine size of about $100-200 \mathrm{~nm}$, which was almost independent on sintering temperature. The $\mathrm{SiC}$ particles located around the $\beta-\mathrm{Si}_{3} \mathrm{~N}_{4}$ grains and are suggested to prohibit the densification of the $\mathrm{Si}_{3} \mathrm{~N}_{4}$ matrix. The microstructure contains a large fraction of pores as can be seen in Figure 10 and 11. The pore size distribution in the sample with $50 \% \mathrm{SiC}$ is shown in Figure 11 indicating the very fine pore size. The needle like shape is typical for the $\beta$ $\mathrm{Si}_{3} \mathrm{~N}_{4}$ phase and the irregular shape of grains is recognized as the $\alpha-\mathrm{Si}_{3} \mathrm{~N}_{4}$ phase (see Figure 11)

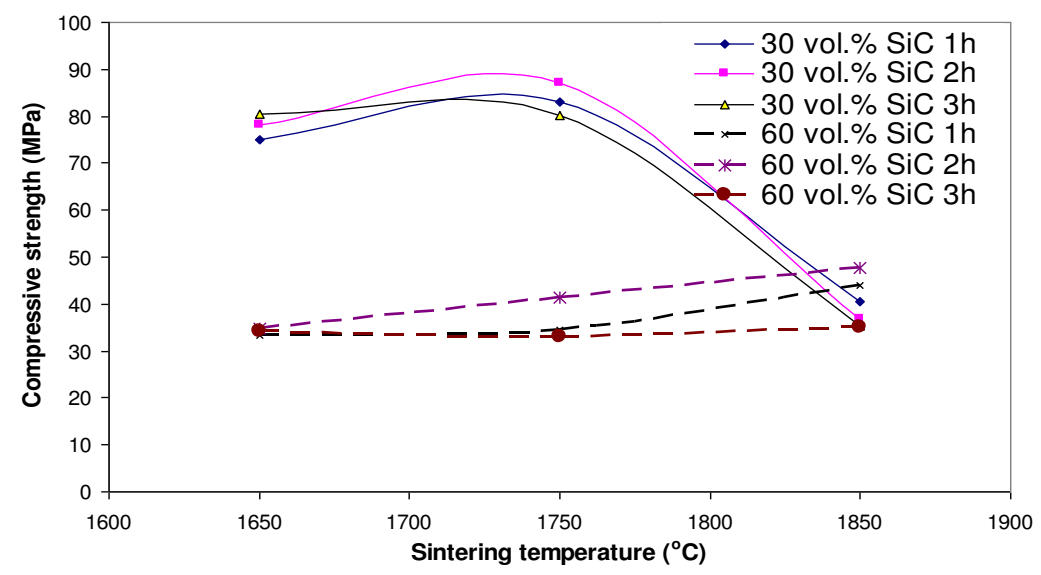

Figure 5. Effect of sintering temperature on the compressive strength for different amount of $\mathrm{SiC}$ and different sintering time. 
(a)

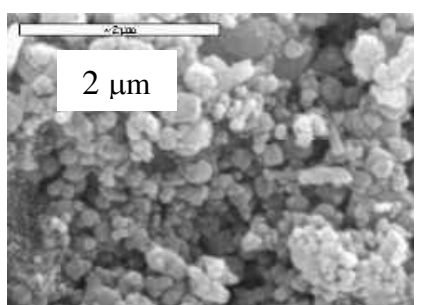

(c)

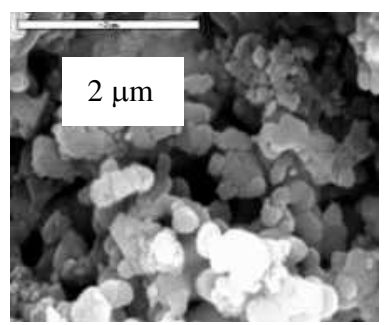

(b)

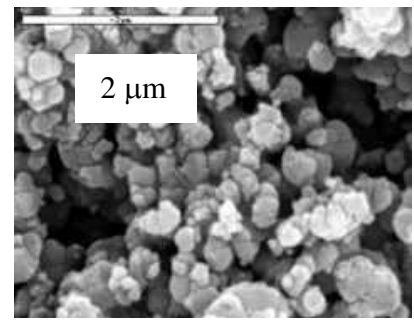

(d)

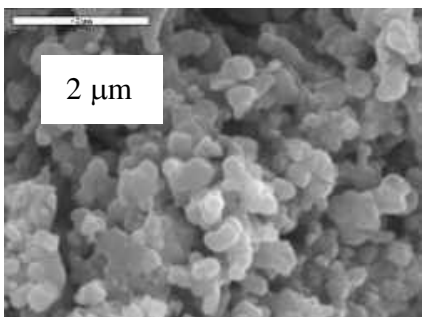

Figure 6. SEM micrograph of 30 vol\% SiC samples: a) green part, b) sintered at $1650^{\circ} \mathrm{C}$ for $\left.1 \mathrm{~h}, \mathrm{c}\right)$ sintered at $1650^{\circ} \mathrm{C}$ for $2 \mathrm{~h}$, and d) sintered at $1650^{\circ} \mathrm{C}$ for $3 \mathrm{~h}$.

(a)

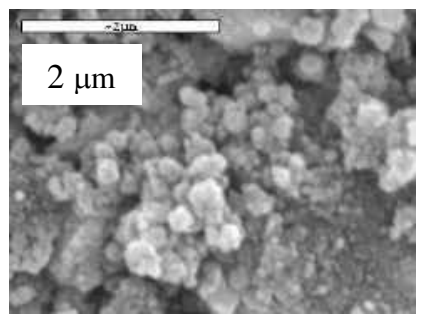

(c)

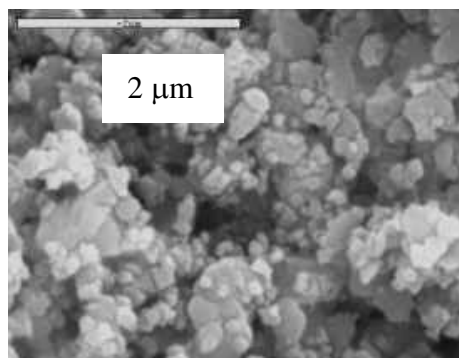

(b)

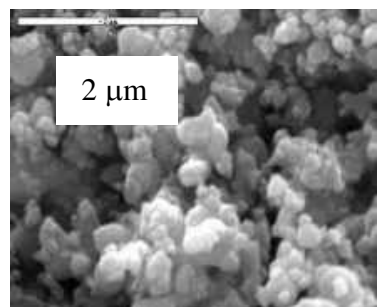

(d)

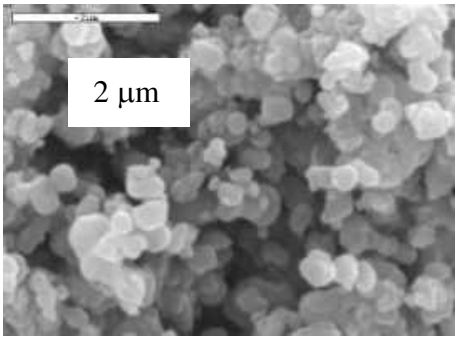

Figure 7. SEM micrograph of $60 \mathrm{vol} \% \mathrm{SiC}$ samples: a) green part, b) sintered at $1650^{\circ} \mathrm{C}$ for $1 \mathrm{~h}, \mathrm{c}$ ) sintered at $1650^{\circ} \mathrm{C}$ for $2 \mathrm{~h}$, and d) sintered at $1650^{\circ} \mathrm{C}$ for $3 \mathrm{~h}$. 
(a)

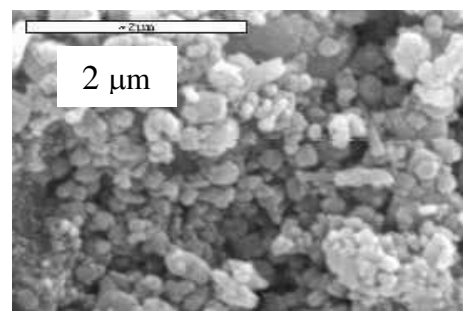

(c)

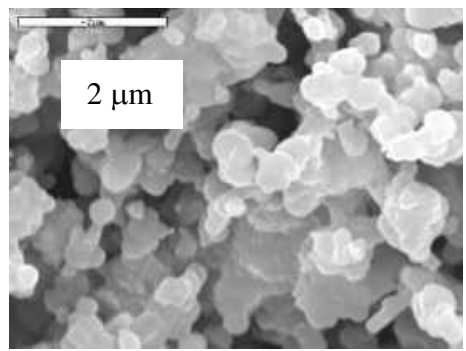

(b)

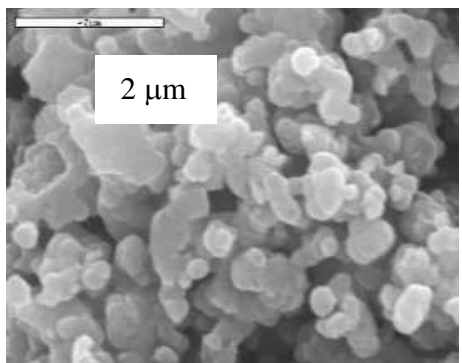

(d)

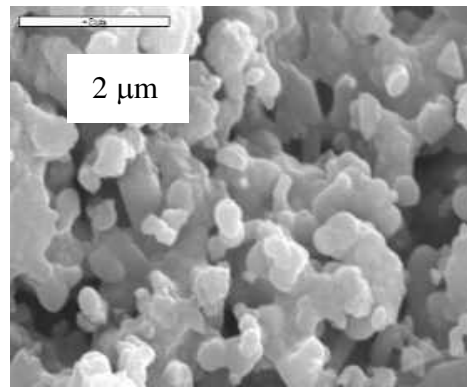

Figure 8. SEM micrograph of $30 \mathrm{vol} \% \mathrm{SiC}$ samples: a) green part, b) sintered at $1750^{\circ} \mathrm{C}$ for $1 \mathrm{~h}, \mathrm{c}$ ) sintered at $1750^{\circ} \mathrm{C}$ for $2 \mathrm{~h}$, and d) sintered at $1750^{\circ} \mathrm{C}$ for $3 \mathrm{~h}$.

(a)

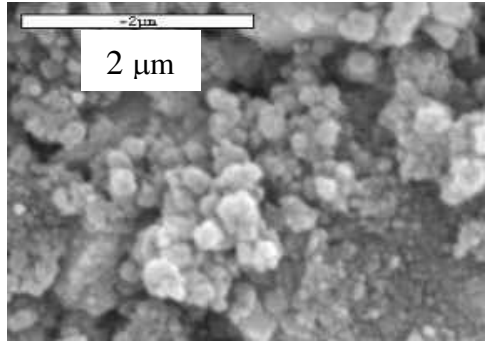

(c)

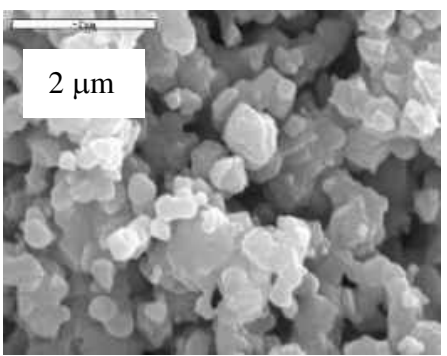

(b)

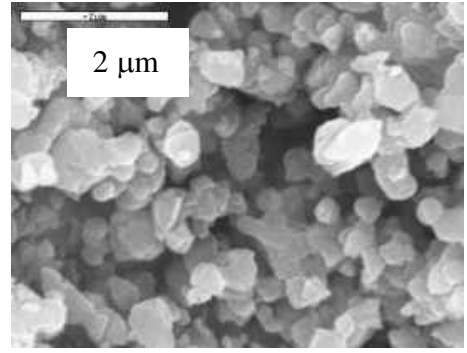

(d)

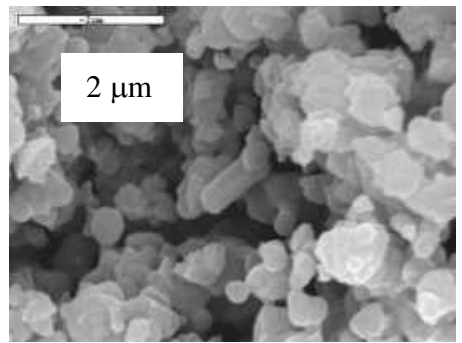

Figure 9. SEM micrograph of $60 \mathrm{vol} \% \mathrm{SiC}$ samples: a) green part, b) sintered at $1750^{\circ} \mathrm{C}$ for $1 \mathrm{~h}, \mathrm{c}$ ) sintered at $1750^{\circ} \mathrm{C}$ for $2 \mathrm{~h}$, and d) sintered at $1750^{\circ} \mathrm{C}$ for $3 \mathrm{~h}$. 
(a)

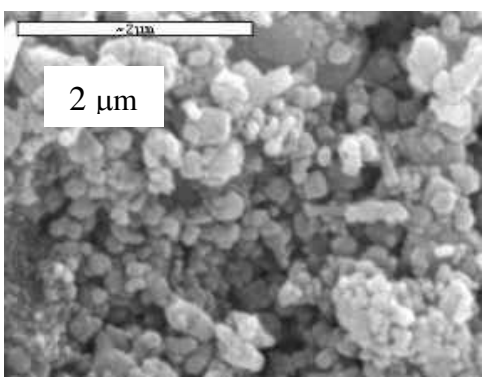

(c)

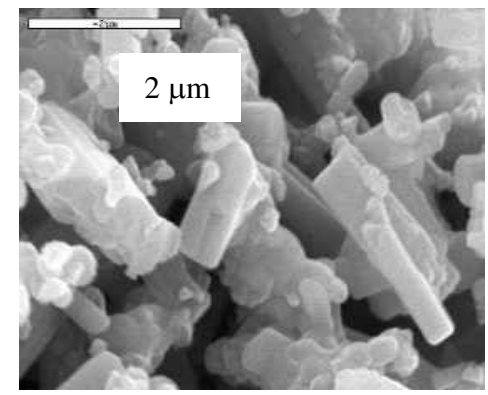

(b)

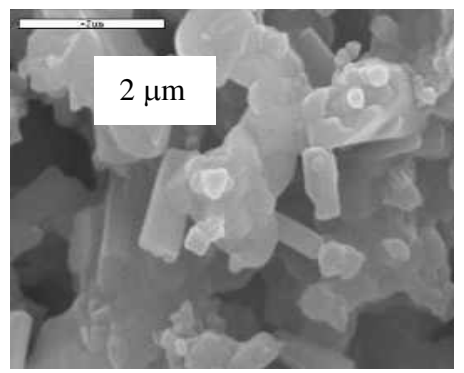

(d)

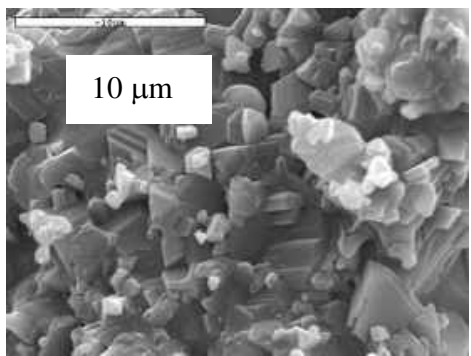

Figure 10. SEM micrograph of 30 vol\% SiC samples: a) green part, b) sintered at $1850^{\circ} \mathrm{C}$ for $1 \mathrm{~h}, \mathrm{c}$ ) sintered at $1850^{\circ} \mathrm{C}$ for $2 \mathrm{~h}$, and d) sintered at $1850^{\circ} \mathrm{C}$ for $3 \mathrm{~h}$.

(a)

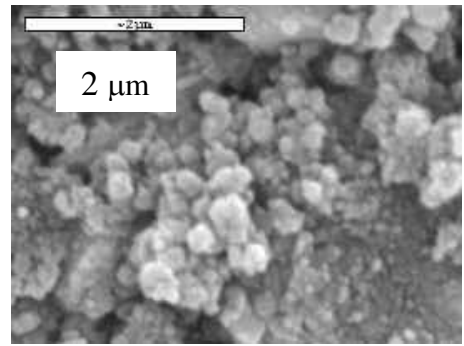

(c)

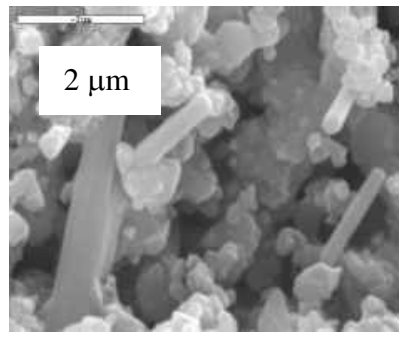

(b)

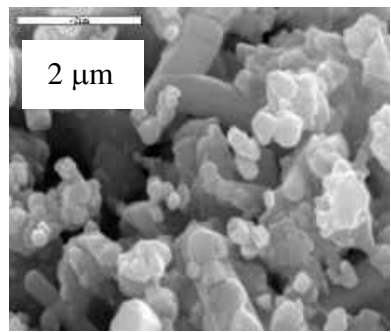

(d)

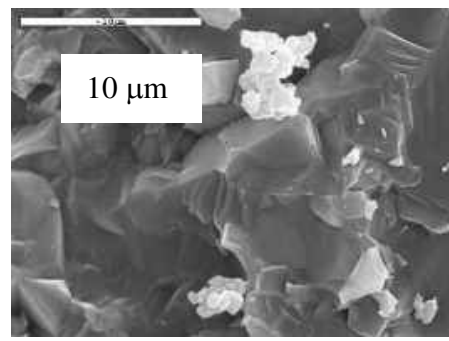

Figure 11. SEM micrograph of 60 vol\% SiC samples: a) green part, b) sintered at $1850^{\circ} \mathrm{C}$ for $\left.1 \mathrm{~h}, \mathrm{c}\right)$ sintered at $1850^{\circ} \mathrm{C}$ for $2 \mathrm{~h}$, and d) sintered at $1850^{\circ} \mathrm{C}$ for $3 \mathrm{~h}$. 


\section{CONCLUSIONS}

Porous $\mathrm{Si}_{3} \mathrm{~N}_{4} / \mathrm{SiC}$ nanocomposites ceramics were successfully fabricated using reaction between $\mathrm{Si}_{3} \mathrm{~N}_{4}$ and $\mathrm{C}$ powder under $\mathrm{N}_{2}$ atmosphere. The $\mathrm{SiC}$ nanoparticles were formed due to the use of nano-sized carbon powder. However, the $\mathrm{Si}_{3} \mathrm{~N}_{4}$ would decompose at the high temperature $\left(1850^{\circ} \mathrm{C}\right)$ and some $\mathrm{Si}$ could be seen in the porous nanocomposites. The porosity of the $\mathrm{Si}_{3} \mathrm{~N}_{4} / \mathrm{SiC}$ nanocomposites can be controlled by altering the content of carbon and by the green density. The total porosity of $\mathrm{Si}_{3} \mathrm{~N}_{4} / \mathrm{SiC}$ nanocomposites obtained by this technique was ranged from 50 to $65 \%$. The strength of $\mathrm{Si}_{3} \mathrm{~N}_{4} / \mathrm{SiC}$ nanocomposites depends mainly on the sintering temperature, and the holding time of the sintering. The best holding time for sintering at $1650^{\circ} \mathrm{C}$, $1750^{\circ} \mathrm{C}$, and $1850^{\circ} \mathrm{C}$ are 2,1 , and $0.5 \mathrm{~h}$ respectively. The formation of elongated $\beta-\mathrm{Si}_{3} \mathrm{~N}_{4}$ grains and reinforced nano-SiC particles was the main reason for good mechanical properties

\section{REFERENCE}

[1] M. K. Hoa, M. Lu and Y. Zhang, "Preparation of porous materials with ordered hole structure," Advances in Colloid and Interface Science, Vol., 121, 2006, pp. 9-23.

[2] K. Maca, P. Dobsak, and A R.Boccaccini, "Fabrication of graded porous ceramics using alumina-carbon powder mixtures," Ceramics International, Vol. 27, 2001, pp. 577-584.

[3] L. Moroni, J. R. de Wijn and C. A. van Blitterswijk, "3D fiber-deposited scaffolds for tissue engineering: Influence of pores geometry and architecture on dynamic mechanical properties" Biomaterials, Vol. 27, 2006, pp. 974-985.

[4] C. E. Wen, Y. Yamada and P. D. Hodgson, "Fabrication of novel TiZr alloy foams for biomedical applications," Materials Science and Engineering: C, Vol. 26, 2006, pp. 1439-1444.

[5] A. Díaz and S. Hampshire, "Characterisation of porous silicon nitride materials produced with starch," Journal of the European Ceramic Society, Vol. 24, 2004, pp. 413-419.

[6] C. Balázsi, B. Fényi, N. Hegman, Z. Kövér, and F. Wéber, "Development of $\mathrm{CNT} / \mathrm{Si}_{3} \mathrm{~N}_{4}$ composites with improved mechanical and electrical properties," Composites Part B: Eng., Vol. 37, 2006, pp. 418-424.

[7] M. Kašiarová, J. Dusza, M. Hnatko and P. Šajgalík, "Microstructure and fracture-mechanical properties of carbon derived $\mathrm{Si}_{3} \mathrm{~N}_{4}+\mathrm{SiC}$ nanomaterials, Materials Science and Engineering: C, Vol. 26, 2006, pp. 862-866 
[8] G. Qi, C. Zhang and H. Hu, "High strength three-dimensional silica fiber reinforced silicon nitride-based composites via polyhydridomethylsilazane pyrolysis," Ceramics International, In Press, 2006.

[9] Y. Zhang, "Microstructures and mechanical properties of silicon nitride bonded silicon carbide ceramic foams," Materials Research Bulletin, Vol. 39, 2004, pp. 755-761.

[10] Y. Hua, L. Zhang, L. Cheng and J. Wang, "Silicon carbide whisker reinforced silicon carbide composites by chemical vapor infiltration," Materials Science and Engineering: A, Vol. 428, 2006, pp. 346-350.

[11] M. I. Jones, M.-C. Valecillos, K.i Hirao and Y. Yamauchi, "Grain growth in microwave sintered $\mathrm{Si}_{3} \mathrm{~N}_{4}$ ceramics sintered from different starting powders," Journal of the European Ceramic Society, Vol. 22, 2002, pp. 2981-2988.

[12] J-F. Yang, G-J. Zhang, N Kondo and T Ohji "Synthesis and properties of porous $\mathrm{Si}_{3} \mathrm{~N}_{4} / \mathrm{SiC}$ nanocomposites by carbothermal reaction between $\mathrm{Si}_{3} \mathrm{~N}_{4}$ and carbon," Acta Materialia, Vol. 50, 2002, pp. 4831-4840.

[13] J. Tsubaki, H. Mori, K. Ayama, T. Hotta and M. Nai, "Characterized microstructure of porous $\mathrm{Si}_{3} \mathrm{~N}_{4}$ compacts prepared using the pyrolysis of polysilazane," Journal of Membrane Science, Vol. 129, 1997, pp. 1-8.

[14] G. J. Zhang, J. F. Yang, Z, Y. Deng, T. Ohji, "Fabrication of Porous Ceramics with Unidirectionally Aligned Continuous Pores," Journal of the American Ceramic Society, Vol. 84, 2001, pp.1395-1397.

[15] J-F. Yang, Z. Y. Deng, and T. Ohji, "Fabrication and characterisation of porous silicon nitride ceramics using $\mathrm{Yb}_{2} \mathrm{O}_{3}$ as sintering additive," Journal of the European Ceramic Society, Vol. 23, 2003, pp. 371-378.

[16] A Pablos, M. Osendi and P. Miranzo, "Correlation between microstructure and toughness of hot pressed $\mathrm{Si}_{3} \mathrm{~N}_{4}$ ceramics seeded with $\beta-\mathrm{Si}_{3} \mathrm{~N}_{4}$ particles," Ceramics International, Vol. 29, 2003, pp. 757-764.

[17] I. G. Cano and M. A. Rodríguez, "Synthesis of $\beta$-Silicon nitride by SHS: fiber growth," Scripta Materialia, Vol. 50, 2004, pp. 383-386.

[18] Y. Inagaki, N. Kondo and T. Ohji, "High performance porous silicon nitrides," Journal of the European Ceramic Society, Vol. 22, 2002, pp. 2489-2494.

[19] J. B. Davis, A. Kristoffersson, E. Carlström, and W. J. Clegg, "Fabrication and crack deflection in ceramic laminates with porous interlayers" Journal of the American Ceramic Society Vol. 83, 2000, pp. 2369- 2374.

[20] Y-S. Oh, W-S. Cho, C-S. Kim, D. S. Lim, and D-S. Cheong, "XPS Investigation of $\mathrm{Si}_{3} \mathrm{~N}_{4} / \mathrm{SiC}$ Nanocomposites Prepared Using a Commercial Polymer," Journal of the American Ceramic Society Vol. 82, 1999, pp. 1076- 1079. 
[21] D. Carroll, A. Weimer, S. Dunmead, G. Eisman, J. Hwang, G. Cochran, D. Susnitzky, D. Beaman, and C. Conner, "Carbothermally prepared nanophase $\mathrm{SiC} / \mathrm{Si}_{3} \mathrm{~N}_{4}$ composite powders and densified parts," $\mathrm{AIChE}$ Journal, Vol.43, 1997, pp. 2624-2635.

[22] K. Ishizaki and T. Yanai, " $\mathrm{Si}_{3} \mathrm{~N}_{4}$ Grain Boundary Reinforcement by $\mathrm{SiC}$ Nanocomposites," Silic. Ind., Vol.7-8, 1995, pp. 215-222.

[23] J. Wan, R. G. Duan and A. L. Mukherjee, Spark plasma sintering of silicon nitride/silicon carbide nanocomposites with reduced additive amounts, Scr. Mater., Vol. 53, 2005, pp. 663-667.

[24] J-F. Yang, T. Ohji, and K Niihara, "Influence of yttria alumina content on sintering behavior and microstructure of silicon nitride ceramics," Journal of American Ceramic Society, Vol. 83, 2000, pp. 2094-2096.

[25] S.A. Baldacim, C. Santos, O. M. Silva, and C.R. Silva, "Mechanical properties evaluation of hot-pressed Si3N4-SiC composites," Int. J. of Refractory Metals \& Hard Materials Vol. 21, 2003, pp. 233-239

\section{طريقة محسنة لصناعة أجزاء مسامية من حبيبات متناهية الصغر مؤلفة من نيتريا}

\section{السيليكون وكربيد السيليكون}

في هذه البحث تمت دراسة خصائص وكيفية تخليق عينات ذو مسامية عالية من نيتريدالسيليكون/كربيدالسيليكون وذللك من حبيبات متتاهية الصغر , و قد تم تصنيع هذه العينات من خليط

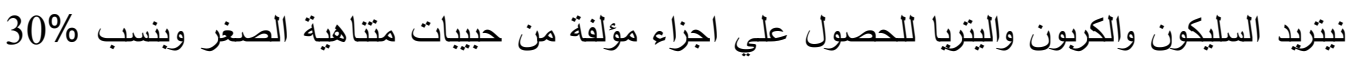
و 60\% من كربيد السليكون في المنتج النهائي, وقد نم كبس الخليط علي البارد عند ضغط 25 ميجا بسكال وتم تلبيد العينات في محيط من غاز النيتروجين عند درجات حراة 1650 ون 1750 و 1850 مئوية ولمدة ساعة وساعتين وثلاث ساعات علي الترتيب وذلك لدراسة تأثثر درجة حرارة التلبيد وكذلك زمن التلبيد علي خصائص المنتج النهائي, وقد تم دراسة خصائص العينات وذللك بإستخدام أنثعة اكس وكذلك بإستخدام الميكرسكوب الآكتروني الماسح. كما تم دراسة الخواص الميكانيكية للعينات عن طريق اجراء اختبار الضغط الميكانيكي عند درجة حرارة الغرفة, وقد خلص البحث الي ان مقاومة العينات تعتمد وبصفة رئيسية علي درجة حرارة التلبيد وكذلك علي زمن التلبيد. 